\title{
The evaluation level of foreign tourists for five-star hotels in Belek in terms of corporate reputation
}

\author{
Cenk Murat Koçoğlu' ${ }^{1}$, Şule Kıyci ${ }^{2}$
}

\begin{abstract}
The purpose of this study is to determine the level of corporate reputation of five-star hotels in Belek for foreign tourists who prefer to stay in this region, and to examine how demographic characteristics of tourists affect corporate reputation level of these hotels. To achieve this aim, first, reputation, corporate reputation and the components of reputation have been examined. The importance of corporate reputation for hotels has been mentioned. What corporate reputation means for the tourism sector and for the enterprises operating in this sector has been explained. The sample of the study is a total of 343 persons of foreign tourists who have stayed in five-star hotels in Belek. Survey technique has been used as data collection method in the study. The questionnaire form has been composed by adapting the questions, which were developed by Fombrun, Gardberg and Sever (2000), to hotel operations. According to the results obtained, foreign tourists generally evaluate the corporate reputation of five-star hotels in Belek in middle level. Nevertheless, it has been determined that products and services, and emotional appeal dimensions are evaluated as more favorable. It is also revealed that foreign tourists, depending on gender, age, income and whether they visited Belek earlier, evaluate the reputation levels of hotels differently.
\end{abstract}

Keywords: Reputation, Corporate reputation, Five-star hotel, Foreign tourists.

\section{Yabancı turistlerin Belek’teki beş yıldızlı otel işletmelerini kurumsal itibar açısından de- ğerlendirme düzeyleri}

\begin{abstract}
$\ddot{O} z$
Bu çalışmanın amacı Belek bölgesindeki beş ylldızlı otellerde konaklama yapmayı tercih eden yabancı turistlerin, bu otellere yönelik kurumsal itibar düzeylerini saptamak ve kurumsal itibar düzeylerini demografik özellikler açısından incelemektir. Bu amaca ulaşmak için öncelikle itibar, kurumsal itibar ve kurumsal itibarın bileşenleri incelenmiştir. Kurumsal itibar kavramının otel işletmeleri için öneminden bahsedilmiştir. Turizm sektörü ve bu sektör içinde faaliyet gösteren işletmeler için kurumsal itibarın ne ifade ettiği açılklanmıştır. Araştırmanın örneklemi Belek'te beş yıldızlı otellerde konaklama yapmış yabancı ziyaretçilerden oluşan toplam 343 kişidir. Araştırmada veri toplama yöntemi olarak anket tekniği kullanılmıştır. Kullanılan anket formu, Fombrun, Gardberg ve Sever (2000) tarafindan geliştirilen soruların otel işletmelerine uyarlanması ile oluşturulmuştur. Elde edilen sonuçlara göre, yabancı turistler Belek'teki beş yıldızlı otel işletmelerinin kurumsal itibarlarını genel olarak orta seviyede değerlendirmektedirler. Bununla birlikte, mal ve hizmetler ile duygusal cazibe boyutların çok daha olumlu değerlendirdikleri belirlenmiştir. Diğer yandan, yabancı turistlerin; cinsiyet, yaş, gelir ve daha önce Belek'e gelme durumlarına göre, otel işletmelerinin itibar düzeylerini farklı değerlendirdikleri ortaya çıkmıştır.
\end{abstract}

Anahtar sözcükler: İtibar, Kurumsal itibar, Beş yıldızlı otel işletmeleri, Yabancı turistler.

$\begin{array}{ll}\text { Geliş Tarihi } & : 27.09 .2018 \\ \text { Kabul Tarihi } & : 01.03 .2019\end{array}$

Alıntı için: Koçoğlu, C.M., Kıycı, Ş. (2019). Yabancı turistlerin Belek’teki beş yıldızlı otel işletmelerini kurumsal itibar açısından değerlendirme düzeyleri. Journal of Tourism Theory and Research, 5(2), 112-122.

\footnotetext{
${ }^{1}$ Sorumlu yazar, Dr. Öğr. Üyesi, Karabük Üniversitesi Safranbolu Turizm Fakültesi, Karabük/Türkiye, Email: cenk-murat@hotmail.com.tr 2 Öğr. Gör., Bülent Ecevit Üniversitesi, Devrek MYO., Zonguldak, Türkiye 


\section{Giriș}

Örgütlerin faaliyetlerini yürüttükleri sektör içinde sürdürülebilir bir başarı elde etmek amacıyla çalışmaları her geçen gün artmaktadır. Örgütlerin karşı karşıya oldukları ekonomik rekabet ortamı, dönemsel krizler, gün geçtikçe artan toplumsal farklılıklar hem ürün kalitesini, hizmet ve müşteri politikalarını etkilemekte hem de o örgütlerin gelecekle ilgili kaygılarını da öncelikli duruma getirmektedir. Bu bağlamda tüm örgütlerin uzun vadede devamlılıklarını sürdürebilmeleri için en değerli varlıkları olan itibarları, sahip oldukları vazgeçemeyecekleri hammaddeleri olarak ifade edilmektedir. Bu hammadde kaynağının kolaylıkla kaybedilebileceği unutulmamalı, olumlu itibar yaratmak amacıyla özenli çalışmalar yaparak sürdürülebilirliği olan faaliyetler gerçekleştirilmelidir. Çünkü itibar, örgütlere uzun vade de fayda sağlayacak bir değer olarak bilinmektedir (Erhan ve Çarıkçı, 2016:354).

Kurumsal itibar kavramı en genel ifadeyle; bir örgütün bütün paydaşları için ne ölçüde güvenilir, saygın ve kıymetli algılandığına dair zaman içinde oluşmakta olan genel kanının bütüncül ifadesi şeklinde açıklanabilmektedir (Gotsi ve Wilson, 2001:29). Bu kavramın son dönemde öneminin artması, işletmelere sağladığ1 rekabet avantajından kaynaklanmaktadır (Greyser, 1999; Dolphin, 2004). Kavram, soyut olup; elle tutulamaz, gözle görülemez fakat örgüte değer katmakta, ender bulunmakta, başkalarınca taklit edilememekte ve yerine başka bir şey konulamamakta olup çok önemli, örgüte özgü bir kaynaktır (Hall, 1993; Roberts ve Dowling, 2002).

İtibar çok boyutlu bir yapıya sahiptir. Etkili bir kurumsal itibar yönetimi için bu kavramı oluşturan temel bileşenleri iyi tanımlamak gerekmektedir. Bu hususta en önemli konu, kurumsal itibarı oluşturan bileşenlerin, farklı paydaş grupları tarafindan algılanmalarında farklı1ıklar olma olasılıklarının olabileceğidir. Örneğin, hissedarlar için bu kavramın öncelikli göstergesi; finansal performansın iyi olması ve yüksek karlılık; örgüt çalışanları içinse iyi bir çalışma ortamı, tatmin edici maddi ve sosyal imkanlar iken; müşteriler içinse sunulan mal ve hizmetlerin kalitesiyle değerlendirilebilmektedir (Barich ve Kotler, 1991; Saxton, 1998; Tolbert, 2000; Dentchev ve Heene, 2004). Ayrica kurumsal itibar kavramı aynı paydaş grubu içinde yer alan farklı özelliklere sahip bireyler tarafindan da farklı şekillerde algılanabilmektedir. Örneğin, farklı demografik değişkenlere sahip müşteriler gibi. Bu durumda örgütün, her bir hedef gruba özel olarak hazırlanmış stratejiler ve politikalar oluşturması gerekmektedir (Alnıaçık vd., 2010:95).

Turizm işletmeleri, ürünlerini turistlere tanıtırken, turistler ile iyi ilişkiler kurabilmeleri ve turistlerin tekrar kendi işletmelerini tercih etmelerini sağlayabilmek amaciyla iyi bir itibara sahip olmak durumundadırlar. Özellikle yabancı turistleri işletmelerine çekebilmek, verimli faaliyetler yürütebilmek ve sahip oldukları potansiyelleri iyi değerlendirebilmek için güçlü bir itibara sahip olmaları gerekmektedir. İtibar uzun yıllar içerisinde sürdürülen çabalar neticesinde oluşmakta; fakat çok kısa bir sürede de kaybedilebilmektedir. Bu sebeple iyi yönetilmesi gereken bir kavramdır. Turistler zaman kısıtlarından dolayı araştıracak vakitleri olmadığında sınırlı alternatifler arasından tercih yapabilmektedirler. Böyle bir durumda da turistlerin ilk seçimini itibarı yüksek işletmelerden yana yapması beklenmektedir (Akgöz, 2009:158-159).

$\mathrm{Bu}$ araştırmada farklı demografik özelliklere sahip katılımcılar tarafından kurumsal itibar kavramının algılanmasında bir fark olup olmadığı incelenmiştir. $\mathrm{Bu}$ amaçla Antalya Belek'te faaliyet gösteren beş yıldızlı otellere yönelik yabancı turistlerin itibar algılarının demografik özelliklerine göre farklılaşıp farklılaşmadığını test etmek amacıyla bir saha araştırması gerçekleştirilmiştir.

Olumlu itibar elde etmek, bunu muhafaza etmek ve devamlılığını sağlamak her sektörde farklı paydaş beklentilerine göre şekillenmektedir. Özellikle turizm endüstrisi içinde hizmet sunmakta olan tüm sektör örgütlerinin, yabancı turistleri de kapsadığı düşünüldügünde bu endüstri içinde itibar kazanmanın ve bunu yönetmenin oldukça zor ve önem arz ettiği görülmektedir (Erhan ve Çarıkçı, 2016:355).

Çalışmanın amacı, emek yoğun sektörlerden biri olan turizm içinde Belek'te faaliyet göstermekte olan beş yıldızlı otellerde konaklama yapan, yabancı turistlerin bu otellere yönelik itibar algılarının demografik değişkenlere göre farkl1lık gösterip göstermediğinin belirlenmesidir. Buna göre devam eden bölümde sırasyyla itibar, kurumsal itibar ve kavramın örgütler için önemi ile kurumsal itibar bileşenleri açılanarak, bu 
kavramının turizm işletmeleri açısından önemi ile ilgili mevcut literatür araştırılmış olup; devamında araştırmanın yöntemi, veri analizi ve bulguları sunulmuştur.

\section{2. İtibar, kurumsal itibar ve örgütler için önemi}

İtibar kavramı, genellikle kişileri tanımlarken kullanılmaktadır. Kavramın ifade ettiği anlamlar içinde saygınlık, beğenilme ve toplum tarafından beklenen davranışı sergileme gibi olumlu düşünceler yer almaktadır. Kişiler için kullanımına alıştığımız itibar kavram1; son dönemde örgütler içinde kullanılmakta olduğu görülmektedir. Örgütlerin de yapıcı ve geleceğe dönük güven verici davranışlarda bulundukları takdirde toplum içindeki tüm paydaşlarından destek bulabilecekleri görülmektedir (Erhan ve Çarıkçı, 2016:355). Kavramın örgütlere hem maddi hem de maddi olmayan birçok yararı olduğu görülmektedir.

Kurumsal itibar, kurum paydaşlarında zaman içinde oluşan, kurum ile ilgili imajın ve fiili davranışlarının algılanması ve yorumlanmasına bağlı olarak kuruma atfettikleri niteliklerin tamamını ifade etmektedir (Fombrun ve Shanley, 1990:235). Bir örgüt için paydaşlar; hissedarlar, müşteriler, çalışanlar, ortaklar, hükümet, medya mensupları, yerel toplum ve doğal çevreden oluşmaktadır (Neville vd., 2005:1186). Tüm paydaş grupların örgüte yönelik ortak fikri, örgütün ne olduğuna ilişkin düşünceleri, duyguları, inançları, alg1lamaları ve örgütle kurdukları bağlantıların toplamı kurumsal itibar olarak açıklanmaktadır (Nakra, 2000:35; Chun, 2005:105; Neville vd., 2005:1186). Kurumsal itibar paydaşların zihninde oluşmakta, değerlendirilmekte ve gelişmektedir (Alnıaçık, Alnıaçık ve Genç, 2010:95). Özetle; kurumsal itibar, örgütlerin saygınlığını, güvenilirliğini ve değerini anlatmak amacıyla kullanılan ve örgütün ilişkide bulunduğu farklı gruplar tarafından nasıl bir yere sahip olduğunu göstermeye yarayan bir kavramdır (Alnıaçık ve Alnıaçık, 2009:47).

Kurumsal itibar, örgütün geçmişine dayanan bir kavram olup; gelecekteki davranışına ilişkin beklentileri etkilemektedir (Gümüş ve Öksüz, 2009). Bu kavram, Soyut bir varlık olarak, turizm işletmeleri için en önemli stratejik kaynaklardan biridir (Flanagan ve O'shaughnessy, 2005:445). Uzun vade de örgütler için rekabet avantajı yaratabilecek önemli faydalar sağlamaktadır (Fombrun, 1996:57). Birçok örgüt, en önemli varlığının kendi ismi ve itibarı olduğunun farkındadır. İyi bir itibar ile örgütün finansal performansı arasında pozitif ilişki olduğu (Roberts ve Dowling, 2002), çal1şanlarının performansı ve işletmeye bağl1lığını arttırdığı (Dutton vd., 1994), marka denkliği, memnuniyet ve başkalarına tavsiye etme davranışına katkı sağladığı (Koçoğlu, 2018a; Koçoğlu 2018b), kalifiye çalışanları örgüte çektiği (Stuart, 2002), müşteri bağlılığını arttırdığı ve pazarda rekabet avantajı sağladığı, örgütün mal ve hizmetlerine yönelik talebi olumlu yönde etkilediği (Yoon vd., 1993), yatırımcıları örgüte çektiği, aracılar ve tedarikçilerle daha avantajlı iş olanakları sağladığını ortaya koymaktadır (Fombrun ve Shanley, 1990; Aln1açık vd., 2010:96).

Güçlü bir kurumsal itibar oluşturma ve bunu sürdürebilme, rekabetin yoğun bir şekilde yaşandığı günümüzde örgütler için son derece önem arz etmektedir. Toplum farklı medya kanalları aracılığıyla işletmenin faaliyetleri hakkında bilgi sahibi olabilmektedir. Buna ilaveten; kurumsal itibar hem finansal hem de finansal olmayan sonuçları etkilemesi sebebiyle kritik bir role sahiptir (Shamma ve Hassan, 2009:327). Bu sebepten ötürü; örgüt performansı üzerinde birçok etkisi bulunan bu kavramın iyi yönetilebilmesi gerekmektedir.

\subsection{Kurumsal itibarın bileșenleri}

İtibar "değerler" üzerinden yönetilmeye çalışılan bir kavramdır. Değerler ise toplumun tanımladığı; içinde etik, şeffaflık, açıklık ve hesap verilebilirlik kavramlarını barındırmaktadır (Kadıbeşegil, 2012:2; Erhan ve Çarıkçı, 2016:355-356). İşletmeler için iyi bir kurumsal itibarı elde etmenin hangi değerlere bağl1 olduğunu tespit etmek, uygulamaya başlamak ve bunu yönetmek zaman alıcı bir süreç olup; kurumlar, bu süreci ürün işlemlerini yavaşlatan bir yatırım olarak değerlendirdikleri dönemden çıkmaya başladıkları görülmektedir (Erhan ve Çarıkçı, 2016:355-356). Bu sebeple; kurumsal itibarı oluşturan bileşenlerin neler olduğu ve hangi bileşenlerin hangi sosyal paydaşlar üzerinde ne kadar etkisinin olduğunu bilmek, kurumsal itibarı yönetmek açısından önceliklidir. Bu bileşenler, kurumsal itibarı pozitif ve negatif yönde nelerin etkilediğini, bu itibardan memnun olan ve olmayanların kimler olduğunu tespit etmeye yaramaktadır (Dörtok, 2004, 69; Yağcioğlu, 2012:25). Kurumsal itibarın unsurları, itibarın hammaddesi olarak görülürken; kurumsal itibarın bileşenlerini ise, itibarın devamlılı̆̆ını sağlayan ve sürekli iyileştirilmesi içinde yönetilmesi gereken bir kavram olarak ifade edilmektedir (Yağc1oğlu, 2012:25). 
Kurumsal itibarın bileșenlerinin, kurum tarafından iyi algılanması ve önem verilmesi, kurumsal itibarın sağlanması ve korunması açısından önemlidir. Bu bileşenler; mal ve hizmetler, müşteri memnuniyeti, liderlik (kurumun temsil edenin liderlik vasfi), kurumsal sosyal sorumluluk, halkla ilişkiler, finansal performans, kurumsal iletişim (örgüt içi ve örgüt dış1 etkin iletişimin sağlanması) ve kurumsal etiktir (kurumun etik ilkelerinin olması ve bunları uygulayarak güvenilir bir çerçeve oluşturması) (Yağcıŏglu, 2012:25). Fombrun ve arkadaşları (2000) ise itibar bileşenlerini duygusal çekim, mal ve hizmet kalitesi, vizyon ve liderlik, işyeri çevresi, sosyal ve çevresel sorumluluk ve finansal performans şeklinde ifade etmektedir (Alnıaçık vd., 2010:102). Fombrun ve Riel (2004), kurumsal itibar bileşenlerini duygusal cazibe, mal ve hizmetler, kurumsal çevre, finansal performans, vizyon ve liderlik ve sosyal sorumluluk olarak ifade etmektedirler (Fombrun ve Riel; 2004:71-75). Sosyal sorumluluk; işletme faaliyetlerinin toplum faydası düşünülerek yürütülmesi olarak açıklanmaktadır. Duygusal cazibe; işletmenin mal ve hizmetlerinin kalitesinin, tüketenler tarafindan beğenilme, saygı görme ve takdir edilme durumunu göstermektedir. Vizyon ve liderlik bileşeninde vizyon, mevcut durum ve gelecek beklentisini uyumlulaştırarak, işletme için arzulanan imajı yaratmak; liderlik, işletme amaçlarını gerçekleştirmek için örgüt faaliyetlerine yön vermek ve etkilemek olarak ifade edilmektedir. Mal ve hizmet; işletmenin ürettiği ürünlerin kalitesi ile tüketenlerin beklentilerini karşılaması olarak açıklanmaktadır. Finansal performans; işletmenin kar arttırmak ve yatırım yapabilmek niyetiyle risk alması ve rekabet edebilmesi özelliğini yansıtmaktadır. Kurumsal çevre; işletmenin iletişim halinde olduğu çevresi olup; işletme hukuk kurallarına ve toplumsal etik kurallarına uymak zorundadır. İşletmenin itibarını, çevresi ile uyumlu bir şekilde etkin yönetilebilmesi için iyi bir iletişim ağının olması gerekmektedir (Akgöz, 2009:165-171).

\subsection{Turizmde kurumsal itibar}

Turizm, insanların boș zamanını ve tasarrufunu nasıl kullanılacağına dair ekonomik bir kararla başlayan ve yatırım, tüketim, istihdam, ihracat ve kamu gelirleri gibi ekonomik boyutları bulunan bir faaliyettir (Önal vd., 2006:137). Farklı bir ifadeyle turizm, insanların ikamet ettikleri yer dışında, ticari bir beklenti olmaksızın yapılan ve yirmi dört saati aşan ya da en az bir gece konaklamadan oluşan geçici seyahatler neticesinde meydana gelen ekonomik, sosyal nitelikli tüketim ilişkilerinin bütünü olarak açıklanmaktadır (Usta, 2009:7; Erhan ve Çarıkçı, 2016:358). Turizm, ülke ekonomisine katk1 sağlamakta, ülkelerin gelişmişlik seviyelerinde etkisi olduğu bilinmektedir. Turizm ile bölgeler arası farklılıklar en aza indirgenmeye çalışılmaktadır. Türkiye sahip olduğu doğal güzellikler, tarihi ve kültürel geçmişiyle turizm faaliyetleri için ideal bir ülkedir. Turizm işletmelerinin ülkenin önemli birer itibar temsilcileri olduğu düşünülmektedir (Erhan ve Çarıkçı, 2016:358). Bu sebeple; turizm işletmelerinin olumlu bir kurumsal itibara sahip olmaları gerekmektedir. İtibar Enstitüsü (Reputation Institute) yöneticilerinden Nicolas Georges Trad; turizm işletmesinin ve o işletmenin bulunduğu ülke, şehir veya bölgenin "itibarı", tatil amaciyla rezervasyon yaptırmanın ön koşulu olarak ifade etmektedir. Bir ülkenin tatil yeri olarak seçilmesi, ülkeyi ziyaret etme talebinin artış göstermesi, o ülkenin itibarı ile doğrudan ilişkilidir (Forbes, 2013). $\mathrm{Bu}$ sebeple turizm işletmelerinin itibarları, ülke itibarından bağımsız olarak düşünülmemektedir. Hizmet kalitesi yüksek ve iyi bir itibara sahip ünlü bir otel zincirinin, terör vb. unsurlar sebebiyle imajı ve itibarı kötü olan bir ülkede faaliyet göstermesi oldukça güç olacaktır. Bunun yanında turizm sektöründe faaliyet gösteren diğer işletmeler (havayolu ve seyahat acenteleri gibi) aralarında uygun ortakliklar kurarak da birbirlerinin itibarlarına olumlu yönde etkileyebilmektedirler (Usta, 2006). Ayrıca, işletme içinde iyi örgütlenmiş çalışanlar olması, hizmet kalitesini olumlu yönde etkileyerek ve müşteri memnuniyetini maksimize edecektir. Tatmin olmuş müşteriler de işletme ile ilgili pozitif düşüncelere sahip olacaktır. Netice de bu durumdan kurumsal itibar olumlu etkilenmiş olacaktır (Arslanergül ve Perçin, 2015:5).

\section{Yöntem}

Araştırmanın amacı Belek'e gelen yabancı turistlerin bu bölgedeki beş yıldızlı otelleri kurumsal itibar açısından değerlendirmelerini belirlemek ve bu değerlendirmelerin, demografik özelliklere göre farklılaşma durumlarını tespit etmektir. Bu amaçla çalışmada betimsel bir araştırma metodu sergilenmiş ve veri toplama yöntemi olarak anket tekniği kullanılmıştır. Kullanılan anket, Fombrun vd. (2000) tarafindan oluşturulmuş olup; ifadeler otel işletmelerine uyarlanarak kullanılmıștır. Araștırmanın kapsamını Belek'e gelen 
ve beş yıldızlı otel işletmelerinde konaklama yapan yabancı turistler oluşturmaktadır. Araştırma esnasında bazı otellerin anket teklifini kabul etmemesi nedeniyle kolayda örnekleme yöntemiyle 350 turistten veri toplanmıştır. 7 anketin eksik ve yanlış doldurulmasından dolay1, analizler 343 anket üzerinden yapılmıştır. Araştırmalarda örnek hacminin, araştırmadaki değişken sayısının en az on katı olması gerektiği belirtilmektedir (Hair vd., 1998; Kline, 2011). Bu çalışmada kullanılan değişken sayısı 20 olduğundan, örnek hacminin yeterli olduğu tespit edilmiştir. Araştırmada analiz yöntemi kapsamında tanımlayıcı istatistiki yöntemlere başvurulmuştur. Hipotezlerin analiz edilmesinde parametrik testlerden, $\mathrm{t}$ testi, ANOVA ve Tukey testleri kullanılmış ve yapı geçerliliğini test edebilmek için açıklayıcı faktör analizi uygulanmıştır.

Araştırmada, Belek'te beş yıldızlı otellerde konaklayan yabanc1 turistlerin, bu otelleri kurumsal itibar açısından değerlendirmelerinin demografik değişkenlere göre farklılaşma durumlarını belirlemek üzere, önceki araştırmalar doğrultusunda (Alnıaçık vd., 2010; Arslanergül ve Perçin, 2015; Erhan ve Çarıkcı, 2016) aşağıdaki hipotezler oluşturulmuştur:

$\mathrm{H}_{1}$ : Yabanc1 turistlerin kurumsal itibarı oluşturan boyutları değerlendirmeleri, cinsiyete göre farklılaşmaktadır.

$\mathrm{H}_{2}$ : Yabancı turistlerin kurumsal itibarı oluşturan boyutları değerlendirmeleri, yaşa göre farklılaşmaktadir.

$\mathrm{H}_{3}$ : Yabanc1 turistlerin kurumsal itibarı oluşturan boyutları değerlendirmeleri, gelirlerine göre farklılaşmaktadır.

$\mathrm{H}_{4}$ : Yabanc1 turistlerin kurumsal itibarı oluşturan boyutları değerlendirmeleri, daha önce Belek'e gelme durumlarına göre farklılaşmaktadır.

\section{Araştırmanın bulguları}

Bu bölümde araştırmaya yönelik tüm bulgulara yer verilecektir.

\section{Demografik bulgular}

Tablo 1'de katılımcıların demografik özelliklerine yönelik bulgular bulunmaktadır. Buna göre, ankete katılan yabancı turistlerin cinsiyetlerine bakıldığında yaklaşık \%55'inin (188 kişi) erkek, \%45'inin (155 kişi) kadınlardan oluştuğu görülmektedir. Turistlerin yaş durumları incelendiğinde, yaklaşık yarısının 26-37 yaş (156 kişi) grubuna ait oldukları ve örneklem grubu içerisinde 25 yaş ve altı (52 kişi) yaş grubunun en az örnekleme sahip olduğu görülmektedir. Araştırmaya katılan turistlerin gelir durumlarına bakıldığında, yaklaşık \%30'unun (105 kişi) 1500-2000 avro gelire sahip olduğu ve örneklem grubu içerisinde en az katılımın 3000 avro ve üstü (42 kişi) gelire sahip turistlerden oluştuğu görülmektedir. Araştırmaya katılan yabancı turistlerin Belek destinasyonuna daha önce gelme durumları incelendiğinde, büyük bir çoğunluğunun (218 kişi) Belek’e ilk defa geldiği görülmektedir.

Tablo 1. Katılımcıların demografik özellikleri

\begin{tabular}{|l|l|l|}
\hline Cinsiyet & Siklık & Yüzde \\
\hline Bayan & 155 & 45,2 \\
\hline Bay & 188 & 54,8 \\
\hline Toplam & 343 & 100,0 \\
\hline Yaş & S1klık & Yüzde \\
\hline 25 yaş ve altı & 52 & 15,2 \\
\hline 26-37 yaş & 156 & 45,5 \\
\hline 38-49 yaş & 76 & 22,2 \\
\hline $50-61$ yaş arası & 59 & 17,2 \\
\hline Toplam & 343 & 100,0 \\
\hline Gelir & S1klık & Yüzde \\
\hline 1500 EU ve altı & 86 & 25,1 \\
\hline 1501-2000 EU & 105 & 30,6 \\
\hline 2001-2500 EU & 57 & 16,6 \\
\hline 2501-3000 EU & 53 & 15,5 \\
\hline 3001 EU ve üstü & 42 & 12,2 \\
\hline Toplam & 343 & 100,0 \\
\hline Belek'e Öncesinde & S1klık & Yüzde \\
Gelme Durumu & & 36,4 \\
\hline Evet & 125 & 63,6 \\
\hline Hayır & 218 & 100,0 \\
\hline Toplam & 343 & \\
\hline
\end{tabular}

Kurumsal itibar düzeyine yönelik açıklayıcı faktör analizi

Kurumsal itibar ile ilgili ölçeğin boyutsal yapılarını, geçerlilik ve güvenilirliklerini belirlemek amacıyla açıklayıcı faktör analizi uygulanmıştır. Araştırmada öncelikle kurumsal itibar düzeyi ölçeğine güvenilirlik analizi yapılmış ve Cronbach Alpha katsayısının ",838” olduğu tespit edilmiştir. Bu değer ölçeğin güvenilir ve geçerli kabul edilebilmesi için gerekli olan 0,70'in üzerinde (Nunnaly ve Bernstein, 1994:265) bir değerdir. 
Tablo 2. Kurumsal itibara yönelik faktör analizi

\begin{tabular}{|c|c|c|c|}
\hline Kurumsal İtibar İfadeleri & Faktör Yükleri & Varyans \% & G. Analizi \\
\hline \multicolumn{2}{|l|}{ Mal ve Hizmetler $(\bar{x}=3,58)$} & \multirow{6}{*}{19,61} & \multirow{6}{*}{,923 } \\
\hline Bu otel sunduğu mal ve hizmetlerin arkasında durur. & ,898 & & \\
\hline Bu otel ödenen paranın karşılığını veren mal ve hizmetler sunar &, 850 & & \\
\hline Bu otel misafirlerine değer katar & ,849 & & \\
\hline Bu otel yenilikçi mal ve hizmetler sunar &, 842 & & \\
\hline Bu otel yüksek kaliteli mal ve hizmetler sunar &, 818 & & \\
\hline Duygusal Cazibe $(\overline{\mathrm{x}}=3,56)$ & & \multirow{4}{*}{13,15} & \multirow{4}{*}{,933 } \\
\hline Bu oteli beğeniyorum. & ,895 & & \\
\hline Bu otel hakkında olumlu duygu ve düşüncelere sahibim. &, 895 & & \\
\hline Bu otele güveniyorum. &, 884 & & \\
\hline \multicolumn{2}{|l|}{ Sosyal Sorumluluk $(\overline{\mathrm{x}}=3,27)$} & \multirow{4}{*}{12,29} & \multirow{4}{*}{,871 } \\
\hline Bu otel topluma yararlı projeler yürütmektedir &, 887 & & \\
\hline Bu otel çevresel sorunlara karșı sorumluluk sahibidir &, 880 & & \\
\hline Bu otelin insanlara karşı davranışları olumludur. &, 812 & & \\
\hline \multicolumn{2}{|l|}{ Finansal Performans $\quad(\overline{\mathrm{x}}=3,49)$} & \multirow{4}{*}{12,19} & \multirow{4}{*}{,879 } \\
\hline Bu otelin rakiplerinden üstün olma eğilimindedir & ,920 & & \\
\hline Bu otel gelecekte büyük gelişim potansiyeline sahiptir. & ,901 & & \\
\hline Bu otel finansal olarak güçlü bir kurumdur. &, 842 & & \\
\hline \multicolumn{2}{|l|}{ Vizyon ve Liderlik $\quad(\overline{\mathrm{x}}=3,02)$} & \multirow{4}{*}{12,06} & \multirow{4}{*}{,887 } \\
\hline Bu otelin geleceğe yönelik net bir vizyonu vardır &, 874 & & \\
\hline $\mathrm{Bu}$ otel lider bir otel işletmesi olma özelliğine sahiptir &, 837 & & \\
\hline Bu otel pazardaki firsatları fark eder ve avantaja çevirir &, 822 & & \\
\hline \multicolumn{2}{|l|}{ Çalışma Ortamı $\quad(\overline{\mathrm{x}}=3,53)$} & & \\
\hline Bu otel çalışmak için iyi bir kurumdur & ,915 & \multirow{3}{*}{12,02} & \multirow{3}{*}{,868 } \\
\hline Bu otelin iyi yönetildiğini düşünüyorum &, 878 & & \\
\hline Bu otelin iyi ve nitelikli çalışanlara sahiptir &, 857 & & \\
\hline \multicolumn{4}{|c|}{$\begin{array}{l}\text { Güvenilirlik Analizi: 0,838 Toplam Varyans: } 81,30 \text { Çıkarım Yöntemi: Temel Bileşenler Analizi, Döndürme } \\
\text { Yöntemi: Kaiser Normalleştirmesi ile Varimax, İterasyon Sayısı: } 6 \\
\text { KMO Uygunluk Ölçütü: } 0,786 \text { Barlett Küresellik Testi x2: } 5041,724 \text { p: } 0,000\end{array}$} \\
\hline
\end{tabular}

Kaiser Normalleştirmesine göre, özdeğeri 1'den büyük olan faktörler dikkate alınarak yapılan faktör analizinde, kurumsal itibara ilişkin ölçeğin 6 faktörden oluştuğu belirlenmiştir. Araştırmanın varyans yüzdesi toplamı 81,30 çıkmıştır. Bu oran \%50'den yüksek olduğu için analizin geçerli olduğunu göstermektedir (Scherer vd., 1988).

Tablo 2 incelendiğinde birinci faktörün "mal ve hizmetler" olduğu ve toplam varyansın yaklaşık \%20'sini açıkladığını, ikinci faktörün "duygusal cazibe" olduğu ve toplam varyansın \%13,15'ini açıkladığ 1 , üçüncü faktörün "sosyal sorumluluk" olduğu ve toplam varyansın \%12,29'unu açıkladığı, dördüncü faktörün "finansal performans" olduğu ve toplam varyansın \%12,19'unu açıkladığı, beşinci faktörün "vizyon ve liderlik" olduğu ve toplam varyansın $\% 12,06$ 'sını açıkladığ ve altıncı faktörün "çalışma ortamı” olduğu ve toplam varyansın \%12,02'sini açıkladığ 1 tespit edilmiştir.
Faktör analizinde ortak varyans (communality) değerlerinin ve ölçekteki maddelerin değerlerinin 0,4 'ten düşük olmaması önemlidir (Field, 2000: 434). Bu faktör analizinde de 0,4 'ten düşük bir değer görülmemektedir. Ayrıca ortaya çıkan her bir faktöre yapılan güvenilirlik analizinde, güvenilirlik değerlerinin “,933” ile “,868” arasında olduğu tespit edilmiştir.

Tablo 2'de ayrica, her bir faktörün ortalamaları da yer almaktadır. Buna göre, yabanc1 turistlerin Belek'teki beş yıldızlı otel işletmeleri kurumsal itibar açısından değerlendirme düzeylerine bakıldığında, en olumlu değerlendirilen boyutun "mal ve hizmetler" olduğu $(3,58)$, bunu sirasıyla, "duygusal cazibe" $(3,56)$, "çalışma ortamı" $(3,53)$, finansal performans $(3,49)$, "sosyal sorumluluk" $(3,27)$ ve " "vizyon ve liderlik" $(3,02)$ boyutlarının izlediği tespit edilmiştir. Yabancı turistlerin Belek'teki otelleri hizmet kalitesi açısından diğer boyutlara göre daha olumlu algılamaları, bu bölgedeki otellerin sunulan hizmeti kaliteli verdiğini göstermektedir. Kurumsal itibarı en iyi açıklayan boyutun 
hizmet kalitesi olduğu düşünüldüğünde, bu boyutun olumlu olması, otel işletmelerinin kurumsal itibar düzeylerini olumlu bir şekilde etkileyecektir.

Demografik Özellikler ile Kurumsal İtibar Algısı Arasındaki İlişkinin Araştırılması

Turistlerin kurumsal itibar algılarının demografik özelliklere göre farklılaşıp farklılaşmadığını belirle- mek için fark testleri gerçekleştirilmiştir. Öncelikle verilerin normal dağılıp dağılmadığını belirlemek için çarpıklık ve basıklık değerlerine bakılmış ve bu değerlerin -1 ve +1 değerleri arasında olduğundan verilerin normal dağ 1 lım gösterdiği (Tabachnick ve Fidell, 2012) tespit edilmiştir.

Tablo 3. Turistlerin demografik özelliklerine göre kurumsal itibarı oluşturan faktörleri değerlendirmeleri ile ilgili analizler

\begin{tabular}{|c|c|c|c|c|c|c|c|c|}
\hline \multirow{2}{*}{ Kurumsal İtibar Faktörler } & \multicolumn{2}{|c|}{ Cinsiyet } & \multicolumn{2}{c|}{ Yaş } & \multicolumn{2}{c|}{ Gelir } & \multicolumn{2}{c|}{$\begin{array}{c}\text { Belek'e Öncesinde } \\
\text { Gelme Durumu }\end{array}$} \\
\cline { 2 - 9 } & $\mathrm{t}$ & $\mathrm{P}$ & $\mathrm{F}$ & $\mathrm{P}$ & $\mathrm{F}$ & $\mathrm{P}$ & $\mathrm{t}$ & $\mathrm{P}$ \\
\hline Mal ve Hizmetler & 2,316 &, 021 & 10,45 &, 000 & 10,22 &, 000 & 11,02 &, 000 \\
\hline Duygusal Cazibe &, 328 &, 746 & 7,852 &, 000 & 7,949 &, 000 & 9,983 &, 000 \\
\hline Sosyal Sorumluluk & 2,277 &, 023 & 10,51 &, 000 & 3,639 &, 006 & 1,509 &, 138 \\
\hline Finansal Performans & 1,935 &, 054 & 1,266 &, 286 & 10,69 &, 000 &, 441 &, 670 \\
\hline Vizyon ve Liderlik &, 095 &, 924 & 4,653 &, 003 & 1,466 &, 212 & 3,734 &, 000 \\
\hline Çalıșma Ortamı & 1,146 &, 243 & 1,446 &, 229 & 3,023 &, 018 &, 291 &, 771 \\
\hline
\end{tabular}

Yabanc1 turistlerin demografik özelliklerine bağlı olarak, kurumsal itibarı oluşturan faktörleri değerlendirmelerinde bir farklılığın olup olmadığını belirlemek amaciyla " $t$ " testi ve ANOVA yapılmıştır. Turistlerin cinsiyetlerine bağl1 olarak, kurumsal itibarı etkileyen faktörleri değerlendirmelerinin farklı1ık gösterip göstermediğini belirlemek için " $\mathrm{t}$ " testi analizi sonucunda, katılımcıların cinsiyetlerine bağlı olarak kurumsal itibarı oluşturan faktörleri değerlendirirken 2 boyutu farklı algıladıkları tespit edilmiştir. Buna göre kadınların "mal ve hizmetler" boyutunu, erkeklere göre daha olumlu algılarken, "sosyal sorumluluk" boyutunu ise daha olumsuz algiladıkları belirlenmiştir. Bu sonuca göre " $\mathrm{H}_{1}$ : Yabancı turistlerin kurumsal itibarı oluşturan boyutları değerlendirmeleri cinsiyete göre farklılaşmaktadır" hipotezi kısmen kabul edilmiştir. Alnıaçık vd.(2010)'nin yapmış oldukları çalışmalarında da cevaplayıcıların cinsiyetlerine göre kurumsal itibari oluşturan boyutları değerlendirirken farklılıkların olduğu yönündeki neticesi bu çalışmayı destekler niteliktedir (Alnıaçık vd., 2010:105). Oysaki Erhan ve Çarıkçı'nın (2016) yapmış oldukları çalışmalarına göre kurumsal itibari oluşturan boyutlarda, cinsiyete göre anlamlı bir farklılık tespit edilmediği yönündedir (Erhan ve Çarıkçı, 2016:359). Akgöz ve Solmaz (2009) ise, yaptıkları çalışmada kadınların itibar ile ilgili konuları erkeklere kıyasla daha fazla önemsedikleri tespit edilmiștir.
Turistlerin yaş durumlarına göre kurumsal itibarı etkileyen faktörleri değerlendirmelerinin farklılık gösterip göstermediğini belirlemek için "ANOVA" yapılmıştır. Yapılan analiz sonucunda turistlerin yaş durumuna göre 4 boyutu farklı değerlendirdikleri tespit edilmiştir. $\mathrm{Bu}$ farklılığın yönünü belirlemek için yapılan Tukey testine göre, en genç yaş grubunda (25 yaş ve altı) olanlar, en yaşlı grubu (50-61 yaş aralığı) oluşturan turistlere göre, "mal ve hizmetler", "duygusal cazibe", "sosyal sorumluluk" ve "vizyon ve liderlik" boyutlarını daha olumsuz değerlendirmişlerdir. Bu sonuca göre " $\mathrm{H}_{2}$ : Yabanc1 turistlerin kurumsal itibarı oluşturan boyutları değerlendirmeleri yaşa göre farklılaşmaktadır" hipotezi kısmen kabul edilmiştir. Erhan ve Çarıkçı'nın (2016) yapmış oldukları çalışmaya göre de gençlerin, yaşlılara göre itibarın tüm boyutlarını algılamaları daha yüksektir. Turistlerin yaşı büyüdükçe özellikle duygusal çekicilik boyutunun itibar algısında bir düşüş yaşanmakta; bu düşüşün sebebiyse yaşı büyük turistlerin beklentilerinin de artması olarak açıklamaktadırlar. Alnıaçık vd.(2010)'nin yapmış oldukları çalışmada da cevaplayıcıların yaş gruplarına göre kurumsal itibarı oluşturan boyutların değerlendirilmelerinin farklılaşacağı yönündeki netice bu çalışmayı destekler niteliktedir. Oysaki Geçikli vd., (2016) yapmış oldukları çalışmada katılımcıların yaş grupları ile kurumsal itibar bileşenleri arasında yalnızca sosyal so- 
rumluluk bileşeninde bir fark tespit edilmiştir. Bu açıdan bakıldığında otellerin çevreye karşı duyarlılıkları hem bulundukları bölgenin doğal güzelliklerin korunması konusunda hem de daha fazla genç turistin bu otelleri seçmesinde önemli etken olacaktır. Özellikle bu durum kurumsal itibarın sosyal sorumluluk boyutu için oldukça önem teşkil etmektedir. (Erhan ve Çarıkçı, 2016:361) Sosyal sorumluluk çalışmaları ile işletme, yalnızca ekonomik faydaya odaklanmadığını özellikle toplumu düşünen bir kurum olduğunu göstermektedir (Gümüş ve Öksüz; 2012:2144).

Turistlerin gelirlerine göre kurumsal itibarı oluşturan faktörleri değerlendirmelerinde bir farklılık olup olmadığ 1 ANOVA ile analiz edildiğinde; "vizyon ve liderlik" boyutu dışındaki tüm boyutlarda farklılık ortaya çıkmıştır. Bu farklılığın yönünü belirlemek için yapılan Tukey testine göre, 1500 avro ve altında gelire sahip olan turistler, 3000 avro ve üstü gelire sahip olan turistlere göre bu beş boyutu daha olumlu değerlendirmişlerdir. $\mathrm{Bu}$ sonuçlara göre " $\mathrm{H}_{3}$ : Yabanc1 turistlerin kurumsal itibarı oluşturan boyutları değerlendirmeleri gelirlerine göre farklılaşmaktadır" hipotezi kısmen kabul edilmiştir. Alnıaçık vd. (2010)'nin yapmış oldukları çalışmada ise katılımcıların gelir düzeylerine göre kurumsal itibari oluşturan boyutların değerlendirilmelerinde bir farkl1lık olmadığı yönündedir. Geçikli vd. (2016)'nin çalışmasında, gelir durumu ve kurumsal itibar bileşenleri arasından "vizyon ve liderlik" ve "finansal performans" bileşenlerinde farklılık tespit edilmiştir

Son olarak yabancı turistlerin daha önce Belek'e gelme durumlarına göre kurumsal itibarı oluşturan faktörleri değerlendirmelerinde ki farklılığı tespit etmek için $\mathrm{t}$ testi yapılmış ve 3 boyutta farklılık tespit edilmiştir. Buna göre daha önce Belek'e gelen turistler ilk kez gelen turistlere göre, "mal ve hizmetler", "duygusal cazibe" ve "vizyon ve liderlik" boyutlarını daha olumlu değerlendirmişlerdir. Bu sonuca göre " $\mathrm{H}_{4}$ : Yabanc1 turistlerin kurumsal itibar1 oluşturan boyutları değerlendirmeleri daha önce Belek'e gelme durumlarına göre farklılaşmaktadır" hipotezi kısmen kabul edilmiştir. Erhan ve Çarıkçı'nın (2016) yapmış oldukları çalışmaya göre kurumsal itibarı oluşturan boyutların turistlerin daha önce Türkiye'ye gelme durumlarına göre anlamlı bir farklılık tespit edilmiştir. $\mathrm{Bu}$ durumun açıklaması olarak da farklı kültürlerin ilk defa karşılaşmalarında uyumsuzluğun olması fakat daha sonraki zamanlarda ise bu farklılığın farkında olunması ve kabullenilmesi olarak ifade edilmektedir.

\section{Sonuç ve öneriler}

Turizm işletmelerinin kurumsal itibarlarının yüksek olmas1, gelecek yıllarda artması beklenen turist sayıs1 ile birlikte Türkiye'nin de turizm sektörü pastasından alacağı payın artması anlamına gelmektedir. Aynı zamanda turizm sektörünün itibarı, ülkenin itibarı anlamına geldiği için son derece önem arz eden bir konudur.

Küresel rekabet ortamında, turizm işletmelerinin uluslararası bir işletme olabilmesi farklı olması ve fark yaratmasıyla mümkündür. İşletme bu farklılaşmayı kurumsal itibarla sağlayabilmektedir. İyi bir kurumsal itibar yönetimi için turizm işletmesi öncelikle iç ve dış paydaşları belirlemesi gerekmektedir. $\mathrm{Bu}$ aşamadan sonra işletme güçlü ve zayıf yönlerini tespit ederek; durumuna uygun bir planlama yapmas1 gerekmektedir. Tüm bu aşamalar dikkate alınarak oluşturulan itibar iyi bir şekilde yönetildiği takdirde işletme önemli bir rekabet avantaj1 sağlayabilecektir (Akgöz, 2009:178).

Araştırmanın hipotezlerine yönelik sonuçlara bakıldığında; Yabancı turistlerin kurumsal itibarı oluşturan boyutları değerlendirmeleri cinsiyet ve yaş değişkenine göre farklılık gösterdiği fakat gelir değişkenine göre bir farklılık olmadığı tespit edilmiştir. Diğer yandan yabancı turistlerin daha önce Belek'e gelme durumlarına göre kurumsal itibarı oluşturan faktörleri değerlendirmelerinde de bir farklılık tespit edilmiştir. Buna göre daha önce Belek'e gelen turistler ilk kez gelen turistlere göre, "mal ve hizmetler", "duygusal cazibe" ve "vizyon ve liderlik" boyutlarını daha olumlu değerlendirmişlerdir. Bu sonuçlar, daha önce literatürde yer alan Alnıaçık vd. (2010) ile Erhan ve Çarıkçı (2016) tarafından yapılan çalışmaları destekler niteliktedir.

Kurumsal itibar bileşenlerinin algılanan önem derecelerinin katılımcıların yaş grubu, cinsiyet, gelir düzeyi ve daha önce Belek'i ziyaret edip etmeme durumlarına göre farklılaşması da yöneticiler için önemli bir bulgudur. Hangi yaş grubu/cinsiyet/gelir düzeyi/daha önce Belek'i ziyaret edip etmeme durumuna sahip bireylerin, kurumsal itibarın hangi bileşenine ne düzeyde önem vereceğini bilerek uygun strateji ve politikalar geliştirmek, turizm işletmeleri için oldukça önemlidir. 
Bireylerin, bir işletmeye yönelik itibar değerlendirmelerinde işyeri çevresi (çalışanların niteliği, çalışma ortamı, yönetim kademesinin nitelikleri) ve mal/hizmet kalitesini (kaliteli, paranın karşılığını veren, yenilikçi ürünler) öncelikli olarak göz önüne almaları rasyonel bir bulgudur. Bu nedenle, işletme yöneticilerinin de, özellikle gençlerden oluşan hedef gruplara yönelirken bu hususlara dikkat etmeleri, iletişim ve pazarlama faaliyetlerini buna uygun şekilde oluşturmaları yerinde olacaktır. Turizm sektöründe kurumsal itibarın artması için daha fazla çalışma yapılması, literatüre ve uygulayıcılara katk1 sağlayabilecektir.

$\mathrm{Bu}$ çalışmanın belek bölgesinde ve sadece yabancı turistler üzerinde gerçekleştirilmesi en büyük sınırlılık olarak görülmektedir. Gelecekte yapılacak çalışmaların daha farklı destinasyonlarda ve örneklemde gerçekleştirilmesi önem arz etmektedir. Ayrıca araştırmanın daha farklı sosyo-ekonomik yapıya sahip turist gruplarına uygulanması önerilmektedir.

\section{Kaynakça}

Akgöz, E. (2009) Kriz ortamında turizm işletmelerinin rekabet aracı olarak itibar yönetimi. Modern Developmental Trends and Turkish World Conference (pp, 158180).

Akgöz, E., Başak Solmaz (2009). Turizm işletmelerinde itibar yönetimi, 19, 23-41.

Alnıaçı, E. ve Alnıaçı, Ü. (2009), Kurumsal itibar ve bölgesel kalkınmadaki önemi. Balıkesir Üniversitesi Burhaniye MYO Bölgesel Kalkınma Kongresi (pp. 47-54).

Alnıaçık, E., Alnıaçık, Ü. ve Genç, N. (2010). Kurumsal itibar bileşenlerinin algılanan önemi demografik özelliklerden etkilenmekte midir?. Balıkesir Üniversitesi Sosyal Bilimler Enstitüsü Dergisi, 13(23), 93-114.

Arslanergül, B. D., Perçin Şahin, N. (2015). Otel işletmelerinde kurumsal itibar yönetimi: Kapadokya örneği, Kapadokya Turizm Paneli (1-9).

Barich, H., P. Kotler, (1991). A framework for marketing image management. Sloan Management Review, 32(2), 94-109.

Chun, Rosa, (2005). Corporate reputation: meaning and measurement. International Journal of Management Reviews, 7(2), 91-109.

Dentchev, N. A. ve A. Heene, (2004). Managing the reputation of restructuring corporations: send the right signal to the right stakeholder. Journal of Public Affairs, 4(1), 56-70.

Dolphin, R.R. (2004). Corporate reputation: a value creating strategy. Corporate Governance, 4(3), 77-92.

Dörtok, A. (2004). Kurumsal itibarınızdan kaç sıfir atabilirsiniz?. İstanbul: Rota Yayınlarl.

Dutton, J.E., Dukerich, J.M. and Harquail, C.V., (1994). Organization images and member identification. Administrative Science Quarterly, 39, 239-263.

Erhan, T., İ. H. Çarıkçı (2016). Rus paydaşların türkiye'deki oteller hakkında kurumsal itibar algısı: antalya bölgesindeki beş yıldızlı rus otel müşterileri üzerine bir araştırma. Süleyman Demirel Üniversitesi İktisadi ve İdari Bilimler Fakültesi Dergisi, 21(2), 353-362.

Field, A. (2000), Discovering statistics using spss for windows, London: SAGE Publication.

Flanagan, D. J., K. C. O'Shaughnessy, (2005). The effect of layoffs on firm reputation. Journal of Management, 31(3), 445-463.

Fombrun, C. J., (1996), Reputation: Realizing value from the corporate image. Harvard Business School Press, Boston, MA.

Fombrun, C., Shanley, M. (1990). What's in a name? Reputation building and corporate strategy. Academy of Management Journal, 33(2), 233-258.

Fombrun, C.J., Gardberg, N. A., Sever, J. W. (2000). The reputation quotient: A multi-stakeholder measure of corporate reputation. The Journal of Brand Management, 7(4), 241-255.

Geçikli, F., M. S. Erciş ve M. Okumuş (2016). Kurumsal itibarın bileşenleri ve parametreleri üzerine deneysel bir çalışma: Türkiye'nin öncü kurumlarından biri. Atatürk Üniversitesi Sosyal Bilimler Enstitüsü Dergisi, 20(4), 1549-1562.

Gotsi, M., Wilson, A.M. (2001). Corporate reputation: Seeking a definition. Corporate Communications, 6(1), 24-30.

Greyser, S. (1999). Advancing and enhancing corporate reputation. Corporate Communications, 4(4), 177-181.

Gümüş, M., B. Öksüz (2009). Turizm işletmelerinde kurumsal itibar yönetimi. Ankara: Nobel Yayınları.

Hall, R. (1993). A framework linking intangible resources and capabilities to sustainable competitive advantage. Strategic Management Journal, 14(8), 607-618.

http://www.forbes.com/sites/brucerogers/2013/05/17/594/ Erişim Tarihi: 03.07.2018. 
Kadıbeşegil, S. (2012). İtibar yönetimi itibarınızı yönetmekten daha önemli işiniz var mı?, Mediacat Kitapları, İstanbul.

Koçoğlu, C. M. (2018a). Yerli Turistlerin Kurumsal İtibar Algılarının Marka Denkliğine Etkisi: Türk Hava Yolları Örneği. Turizm Akademik Dergisi, 5(2), 109-127.

Koçoğlu, C. M. (2018b). Turizm eğitimi veren yükseköğretim kurumlarının itibar bileşenlerinin öğrencilerin memnuniyeti ve tavsiye etme davranışı üzerindeki etkisi. Eskişehir Osmangazi Üniversitesi İktisadi ve İdari Bilimler Dergisi, 13(2), 23-44.

Nakra, P. (2000). Corporate reputation management: CRM with a strategic twist?. Public Relations Quarterly, $45(2), 35-42$.

Neville, B.A., S.J., Bell, B., Mengüç (2005). Corporate reputation, stakeholders and the social performance-financial performance relationship. European Journal of Marketing, 39(9/10), 1184-1198.

Nunnally, J. C., Bernstein I. H. (1994), Psychometric Theory, Third Edition, New York:McGraw-Hill.

Önal, Y. B., E. Düzakın, H. Çiftçi (2006), Ekonomik Büyümenin Yükselen Değeri Turizm ve Türkiye Ekonomisine Etkisinin Analizi, İstanbul:Kare Yayınları.

Roberts, P.W., G.R. Dowling (2002). Corporate reputation and sustained superior financial performance. Strategic Management Journal, 23(12), 1077-1093.

Saxton, M. K., (1998). Where do corporate reputations come from?. Corporate Reputation Review, 1(4), 393-399.

Scherer, R. Wiebe, F..A., Luther, D.C., Adams,J.S. (1988). Dimensionality of coping: factorstability using the ways of coping questionnaire. Psychological Report, $62,763-770$.

Shamma, Hamed M., S. S. Hassan (2009). Customer and non-customer perspectives for examining corporate reputation. Journal of Product \& Brand Management, 18(5), 326-337.

Stuart, H. (2002). Employee identification with the corporate identity. International Studies of Management and Organization, 32(3), 28-44.

Tabachnick, B. G., Fidell, L. S. (2012), Using multivariate statistics, Sixth Edition, Boston:Pearson.

Tolbert, S. L. (2000). A Conceptual Framework and Empirical Test of The Antecedents and Consequences of Corporate Reputation (Doctoral dissertation), Ohio State University.

Usta, M. (2006). Örgüt kültüründe halkla ilişkiler ve itibar yönetimi ege, akdeniz bölgelerindeki turizm işletmeler örneği (Yüksek Lisans Tezi), Dokuz Eylül Üniversitesi.

Usta, Ö. (2009), Turizm Genel ve Yapısal Yaklaşım, Detay Yayınc1lık, Ankara.

Yağcıŏlu, A. (2012). İtibar yönetimi kavramının işlevselliği ve itibar unsurlarının birbiriyle ilişkisi: otel işletmeleri açısından bir uygulama (Yüksek Lisans Tezi), Balıkesir Üniversitesi.

Yoon, E., Guffey, H.J., Kijewski, V. (1993). The effects of information and company reputation on intentions to buy a business service. Journal of Business Research, 27(3), 215-228. 


\section{Extended abstract in English}

In this study, it is examined whether there is a difference in the perception of the concept of corporate reputation by the participants with different demographic characteristics. For this purpose, a field research was conducted in order to test whether the perceptions of reputation of foreign tourists towards the five star hotels active in Antalya Belek differ according to their demographic characteristics.

In this study, a descriptive research method was used and as a data collection method, survey technique was used. The questionnaire used in the study was created by Fombrun et al. (2000) and expressions were adapted to the hotel business. The scope of the research consists of foreign tourists coming to Belek and staying in five-star hotels. As some hotels did not accept the questionnaire during the research, data collected from 350 tourists by easy sampling method. Because of incomplete and inaccurate filling of the 7 questionnaires, the analyzes were conducted on 343 questionnaires. It is stated that the sample volume should be at least ten times the number of variables in the research (Hair et al., 1998; Kline, 2011). Since the number of variables used in this study was 20 , the sample volume was found to be sufficient. In the research, descriptive statistical methods were applied within the scope of the analysis method. In the analysis of hypotheses, from parametric tests, $t$ test, ANOVA and Tukey tests were applied and explanatory factor analysis was used to test the construct validity.

In order to determine the differentiation status of foreign tourists' perception of corporate reputation, staying in five star hotels in Belek, according to demographic variables, the following hypotheses were formed in the light of previous researches (Alnıaçık et al.,2010; Arslanergül and Perçin, 2015; Erhan and Çarıc1, 2016):

$\mathrm{H}_{1}$ : Foreign tourists' evaluation of the dimensions of corporate reputation, differs in terms of gender.
$\mathrm{H}_{2}$ : Foreign tourists' evaluation of the dimensions of corporate reputation, differs in terms of age.

$\mathrm{H}_{3}$ : Foreign tourists' evaluation of the dimensions of corporate reputation, differs in terms of income.

$\mathrm{H}_{4}$ : Foreign tourists' evaluation of the dimensions of corporate reputation, differs in terms of according to the situation before the arrival of Belek.

Looking at the results of the hypotheses of the research; it is determined that foreign tourists' evaluation of the dimensions of corporate reputation differ in terms of gender and age variables, but there is no difference according to income variable. In addition to this, there is a difference in evaluating the factors that constitute corporate reputation of foreign tourists who had visited Belek before. According to this, tourists who had been to Belek in the past, evaluated the "goods and services", "emotional attraction" and "vision and leadership" dimensions more positively than the tourists who came to Belek for the first time. These results support the studies conducted by Alnıaçik et al. (2010) and Erhan and Çarıkcı (2016).

It is a rational finding that individuals take into account the workplace environmental (quality of the employees, quality of work environment, quality of management level) and quality of goods/ services (qualified, value-for-money, innovative products). Therefore, it will be appropriate for business managers to pay attention to these issues, especially when they are directed to target groups consisting of young people and establish communication and marketing activities accordingly. Further studies $t_{1}$ increase the corporate reputation in tourism sector will contribute to the literature and the practitioners.

Being conducted only on foreign tourists and Belek region are seen the biggest limitations of this study. It is important that future studies are carried out in different destinations and samples. It is also recommended that the study should be applied to the groups of tourists with different socio-economic structures. 